\title{
Reconstruction of the retroactive principle in the Indonesian criminal Law code based on the value of religious wisdom
}

\author{
Sri Endah Wahyuningsih \\ endah.w@unissula.ac.id \\ Faculty of Law, Islamic University of Sultan Agung Semarang \\ Muchamad Iksan \\ mi214@ums.ac.id \\ Faculty of Law University of Muhammadiyah Surakarta
}

\begin{abstract}
Indonesian Criminal Code that comes from Dutch heritage has to be reconstructed, because it is not in accordance with the state of Indonesia which is now already independent. One of the important principles in the Criminal Code that needs to be reconstructed is the retroactive principle contained in Article 1 paragraph (2) of the Criminal Code. The law can be retroactive as long as it benefits the defendant, not until the convicted person. The purpose of this research is to evaluate retroactive principle in Criminal Code seen from perspective value of religious wisdom, and ideal reconstruction of retroactive principle in next Criminal Code in accordance with perspective value of religious wisdom. Approach method in this research was done with normative juridical, the data used were secondary data by doing the extracting data bibliography, and data analysis were done by using qualitative descriptive method. Based on the values of religious wisdom, especially from the perspective of Islamic law in the case of any change of laws and regulations, in principle, non-retroactive principle (non-retroactive) is applied, but in certain cases the principle can be disregarded in accordance with the principles of "dlarar" and " maslahat ". The ideal reconstruction of the retroactive principle in the case of a change of laws and regulations after an act has occurred, new laws and regulations shall be applied in accordance with prevailing laws and regulations in favor of the producer and to the benefit of the public for certain offenses determined by Constitution.
\end{abstract}

\section{Keywords : Reconstruction, Retroactive, Criminal Code, Religious Value}




\section{A. INTRODUCTION}

The current Indonesian Criminal Code is a Dutch heritage which came into effect since 1 January 1918 based on S.732 of 1915, so it is not in accordance with the conditions right now-Indonesia is already independent. Therefore, practically, politically, sociologically and adaptively it needs to be replaced by the Criminal Code which is in accordance with the philosophical values of Pancasila.

The reconstruction of the criminal law principles in the Criminal Code as part of the development of the substance of criminal law should begin with the reconstruction of the basic idea/basic concept of thinking which departs from the philosophical foundation of the National Law System. Pancasila is as the ideal national values of life. Therefore, to develop the principles of criminal law, it brings the consequences of the need for national legal science. It is necessary to do legal reconstruction because the reconstruction of the basic idea/concept of thinking is the immaterial aspect of building the psychological values/spirit/attitude/insight/knowledge contained in the sector development of legal culture.

One of the important principles in the Criminal Code that needs to be reconstructed is the legality principle underlying the enforcement of criminal law in Indonesia. Legal principle according to Barda Nawawi Arief has a definition as the legal basis that can be criminalized an act (concerning the source of law) as set forth in Article 1 paragraph (1) of the Criminal Code. Legality principle is viewed from the applicable space of criminal law by time associated with the retroactive principle contained in Article 1 Paragraph (2) of the Criminal Code with the formulation. "If after the act has been done there is a change in the legislation, the most beneficial (favorable) rule for the defendant is used," From the formulation it can be interpreted that the Law may be retroactive for the benefit of the defendant only, not until the convict. Such formulation is certainly unfair and needs renewal. 
According to Barda Nawawi Arief ${ }^{1}$, although Article 1 Paragraph (2) of the Criminal Code contains retroactive provisions ${ }^{2}$, it is more appropriate to say that the article regulates the "Transitional Rule" (ATPER), which is the rule in the transitional period due to changes to the Act. Article 1 paragraph (2) contains the principle that "the provisions of the law applied in the event of any amendment of the Act (in transition) are legal provisions that benefit/lighten the defendant". Thus article 1 verse (2) contains the principle that in the face of two choices of legislation due to a change, it should be "chosen (applied/given) the law favoring/lightening the defendant". Therefore it can be said to contain "subsidiary principle".

The lightest understanding according to Nyoman Serikat Putra Jaya should be interpreted as wide as possible, and not only about the punishment alone, but also on everything from the regulation that has an influence on the judgment of a crime. The determination should be done in concreto and not in abstracto. ${ }^{3}$

However, the broadest meaning is only limited if the change of law is favorable to the defendant, the provision in Article 1 paragraph (2) of the Criminal Code does not cover in terms of provisions that benefit the public interest, meaning that the retroactive principle does not apply if the change is beneficial to the public interest.

Based on the above explanation, Article 1 Paragraph (2) of the Criminal Code which gives the possibility of "retroactive" rules can be said to be more oriented to the interests of the individual ("offender"). This means that irregularities to the principle of "non-retroactive" (ie retroactive) "if they meet the requirements/criteria, that the amendment of Law is beneficial/lighten the defendant (individual), whereas if the change is beneficial to society then the principle does not apply.

\footnotetext{
${ }^{1}$ Barda Nawawi Arief, Perkembangan Asas-Asas Hukum Pidana Dalam Konsep KUHP (Perspektif Perbandingan Hukum Pidana), Pustaka Magister, Semarang, UNDIP, Semarang, 2007, hlm.17-18.

${ }^{2}$ If Article 1 Paragraph (2) is seen as a "retroactive" issue, then the principle is "a retractable law is a law favoring / accepting the defendant", Ibid.

${ }^{3}$ Nyoman Serikat Putra Jaya, Beberapa Pemikiran Ke Arah Pengembangan Hukum Pidana, PT Citra Aditya Bakti, Bandung, 2008 , hlm.7.
} 


\section{B. PROBLEM FORMULATION}

1. How is the principle of retroactive judging from the value of religious wisdom?

2. How is the ideal reconstruction of the retroactive principle in the upcoming Criminal Code design based on the values of religious wisdom?

\section{RESEARCH METHODS}

The method of approach in this research was done by using normative juridical, the data used were secondary data by doing library data extracting, to support secondary data also conducted interview with Islamic law expert that is lecturer and member of Majelis Ulama Indonesia Pusat (Center of Indonesian Council of Ulama). The data obtained then in the analysis with qualitative descriptive method

\section{RESEARCH AND DISCUSSION RESULT}

\section{Non-retroactive Principles in the Criminal Code Judging from the value of religious Wisdom.}

The principle of legality as it is seen as a space of criminal law according to time/"retroactive" is contained in Article 1 paragraph (2) of the Criminal Code with the formula, "If after the act has been done there are changes in legislation, the most beneficial ".

Based on this formula, Article 1 paragraph (2) of the Criminal Code which gives the possibility of the regulation apply "retroactively" can be said to be more oriented to the interest of the individual ("offender"). This means that deviations on the principle of "nonretroactive" (ie retroactive) if it meets the criteria, which the amendment of Law is beneficial/lightens the defendant (individual), 
whereas if the change is beneficial to society then the principle does not apply.

From the above explanation, it can be seen that the formulation of Article 1 paragraph (2) of the Criminal Code (WvS) is less in line with the values of the balance of religious wisdom, because the deviation on non-retroactive principle only oriented to the protection of individual interests alone regardless of the interests of the community.

Deviations from non-retroactive principles that are oriented towards the balance of the protection of individual interests and the protection of the public interest in accordance with the balance of religious wisdom values. In Islamic law there is a rule that states that the criminal penalty in the new Islamic law is applied after the passages are issued and known by the people, it does not apply to the events that occurred before the passages were issued and known. ${ }^{4}$

The logical consequence of the rule is that the criminal code does not have retroactive power (asrar raj'i) and a criminal offense is punished according to the criminal code applicable at the time of the offense. This is affirmed in the Universal Islamic Declaration of Human Rights affirmed: "The principle that criminal law is not retroactive. The provisions of criminal law apply to the law of the law. ${ }^{5}$

The non-retroactive principle of non-retroactivity in Islamic law does not apply rigidly and absolute because in certain cases the principle can be disregarded. The rules of Islamic criminal law have no retroactive power (can be disregarded) except in two respects: ${ }^{6}$

1. Criminal law rules may have retroactive power on very dangerous / dlarar crimes that touch the security and systems of the general public.

2. The rules of criminal law have the force of retroactivity when it is intended for the benefit of the offender and the community.

\footnotetext{
${ }^{4}$ Dalam Ensiklopedi Hukum Pidana Islam, Jilid I, PT.Kharisma Ilmu, Jakarta, 2007, hlm.286.

${ }_{5}$ Universal Islamic Declaration of Human Right, hlm. 9

${ }^{6}$ Ensiklopedi Hukum Pidana Islam, Jilid I, Jilid I-V, PT.Kharisma Ilmu, Jakarta, 2007..hlm.286.
} 
The difference between the two exceptions mentioned above is that in the first exception it is jawazi, that the rules of criminal law can have retroactive power on condition that the public welfare is created, while the second is wujubi (mandatory). Shari'ah (Allah and His Messenger) will not prevent anything unless it is for the benefit of the public. $^{7}$

Based on the values of religious wisdom especially from the perspective of Islamic law is in the case of any change in legislation in principle apply the principle of non-retroactive, but in certain cases the principle can be deviated in accordance with the principle of "dlarar" and "maslahat ". This means that deviations from non-retroactivity principles can be enforced as long as they are very valuable for the security and legal system in society and will bring benefits to the perpetrators, victims and the community. By such a measure, the nonretroactive principle of Islamic law is oriented towards the balance of protection of individual and community interests.

Welfare here is defined as rejecting lost and bring benefits to humans as well as to realize the benefit base on two joints of justice and truth. ${ }^{8}$

The truth according to the Tafsir Al Manar is defined as: "a thing that remains and is in syara ', if it concerns the law of syara', and exists in reality and exists within itself if it is a matter of form '. ${ }^{9}$

The meaning of justice in Tafsir Al Manar is "something you maintain with truth, by not leaning to anything but from two edges or some opposing edges to it or in relation to it". ${ }^{10}$

The application of retroactive (as may be retroactive) as the exclusion of the non-active principle shall be based on the principle of "dlarar" and "benefit" based on the justice and truth joints as above.

The possibility of the above deviation in Islamic law comes from the study of the verses of the law and the causes of descent. All laws

\footnotetext{
${ }^{7}$ Ensiklopedi Hukum Pidana Islam, Jilid I, ibid.

${ }^{8}$ Teungku Muhammad Hasbi Ash Shiddiqie, Falsafah Hukum Islam, Pustaka Rizki Putra, Semarang, 1997, hlm. 324.

${ }^{9}$ Tafsir Al Manar dalam Teungku Muhammad Hasbi Ash Shiddiqie, ibid, hlm. 325. ${ }^{10}$ Ibid.
} 
that prohibit immoral acts are revealed after Islam is spread out. Therefore, criminal acts that occurred prior to the decline of the verses were not sentenced except for the crime of qazaf (accusing others of committing adultery without witness) and hirabah (security disturbances). There are some jurists arguing that the punishment of both crimes is applied even before the downs of the passages containing the two crimes.

The examples of non-retroactive criminal offenses include adultery, adultery is forbidden since the beginning of Islam is revealed. The punishment for the adulterers at that time was mild, namely in the form of house confinement and torture. This is based on QS an-Nisa (4) verses 15-16:

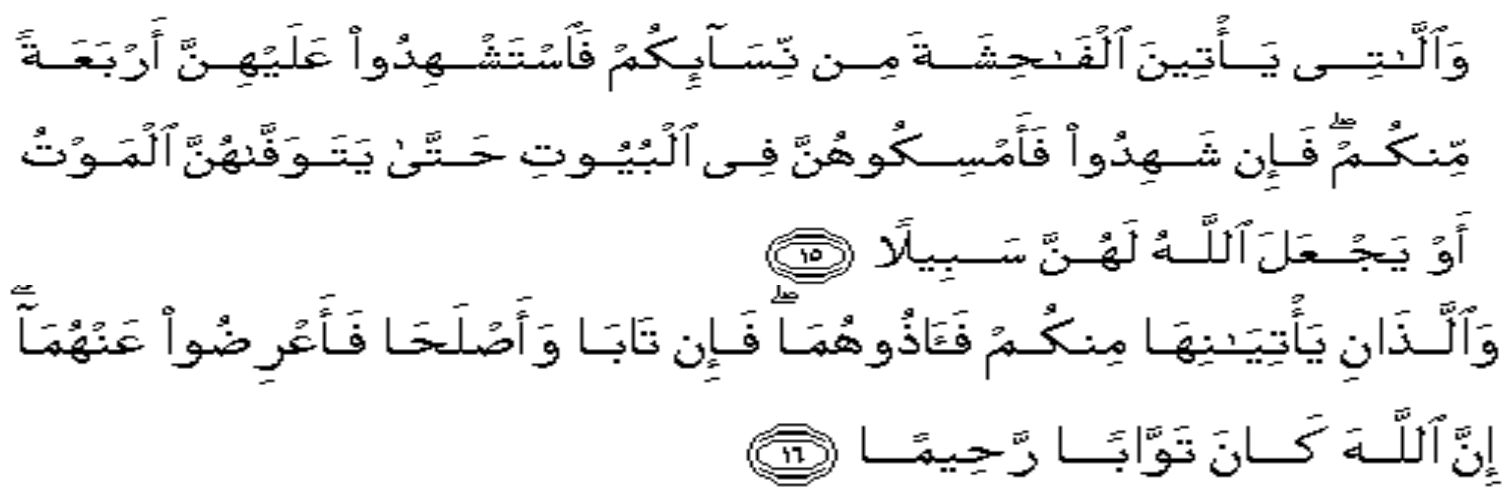

Meaning: And against the women who do wicked deeds there shall be four witnesses among you (who witnessed). Then when they have testified, then brace them (the women) in the house until they meet their death, or until Allah gives another way to him.

And against the two men who commit the heinous deeds among you, then punish both, then if both repent and repair themselves, then leave them alone. Allah is the Receiver of Repentance and the Merciful.

The penalty of adultery is then exacerbated according to QS an-Nur (24) verse 2: 


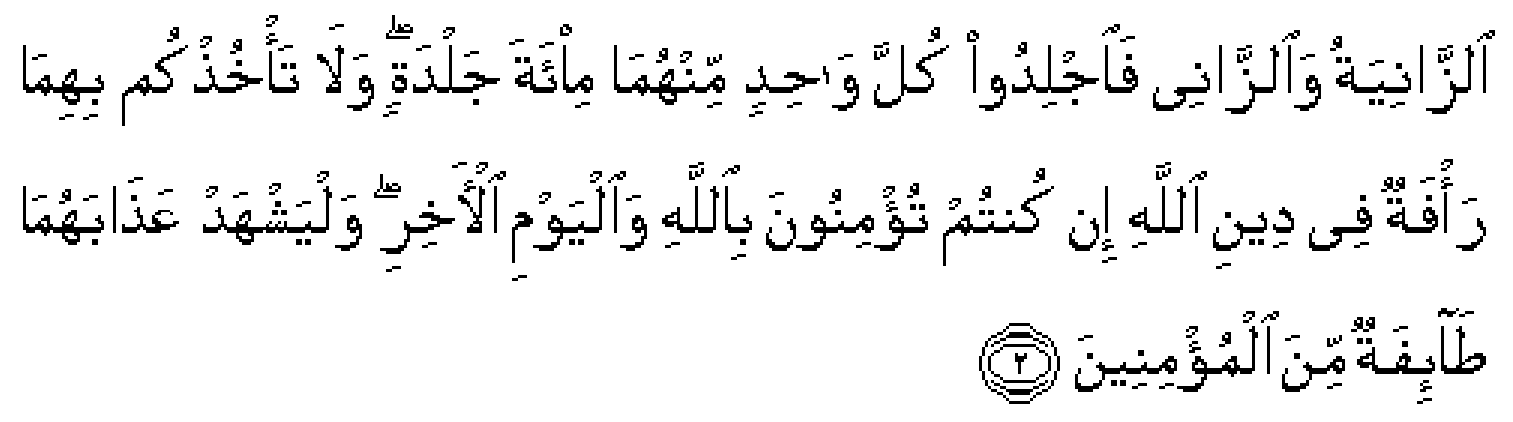

Meaning: Adulterous women and men committing adultery, hence each one of them is one hundred dalas, and let no mercy to both prevent you from practicing the religion of Allah, if ye believe in Allah, and the Hereafter, and let (the execution) of their punishment be witnessed by a group of believers.

If the adultery of the adultery has a retroactive law undoubtedly a hundred times punishment and stoning has been imposed before the passage of this verse. However, the reality is that no one has ever suffered or been stoned before a denial of adultery. Therefore, the passage that punishes adultery has no retroactive power.

Another example is the prohibition of liquor and gambling which is done by phasing. At first, a Muslim was forbidden to approach prayers when he was drunk. It is in accordance with the word of Allah in QS anNisa (4) verse 43:

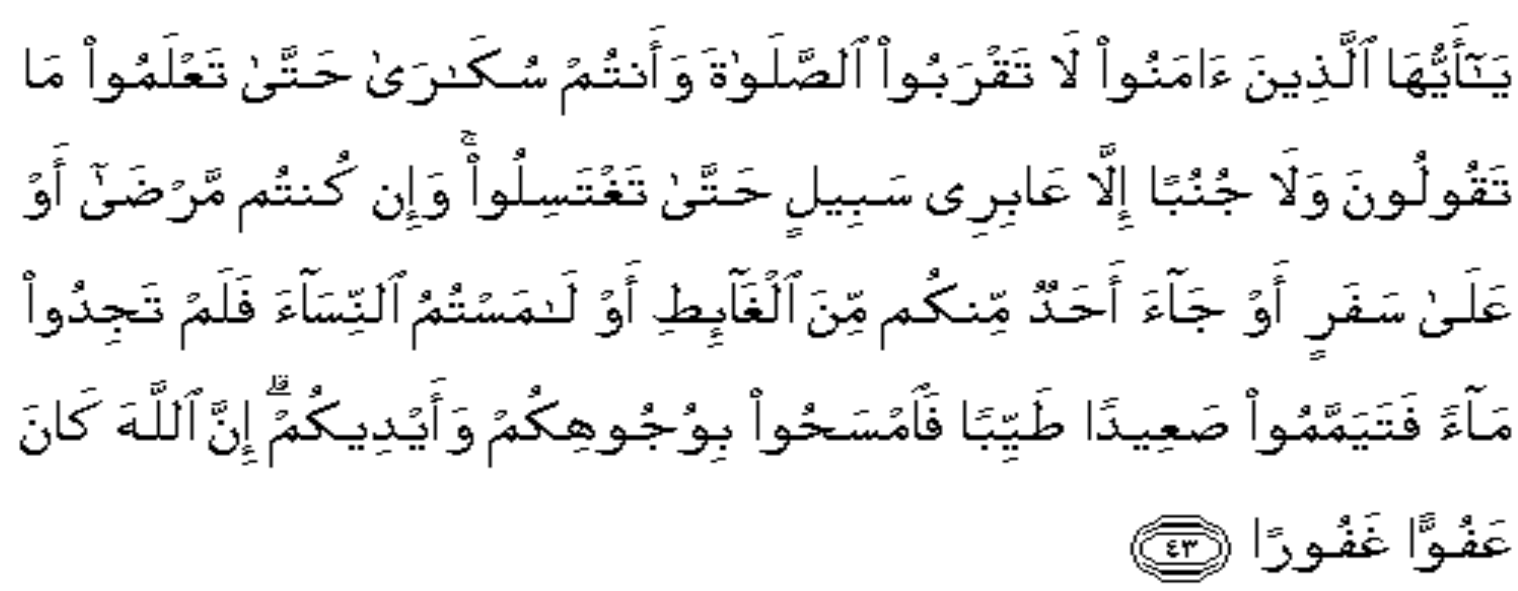

This means: $O$ ye who believe, do not pray, while you are drunk, so you understand what you say, (do not even come to the mosque) while you are in a state of junub, except just pass away, until you take a bath. And if you are sick or in a traveler or come from a place to relieve or you have 
touched a woman, then you have no water, then you grow with good soil (holy); greet your face and your hands. Allah is the Forgiving, the Forgiving.

Allah then explains that these two deeds contain sin and benefit. Allah says in QS al-Baqarah (2) verse 219:

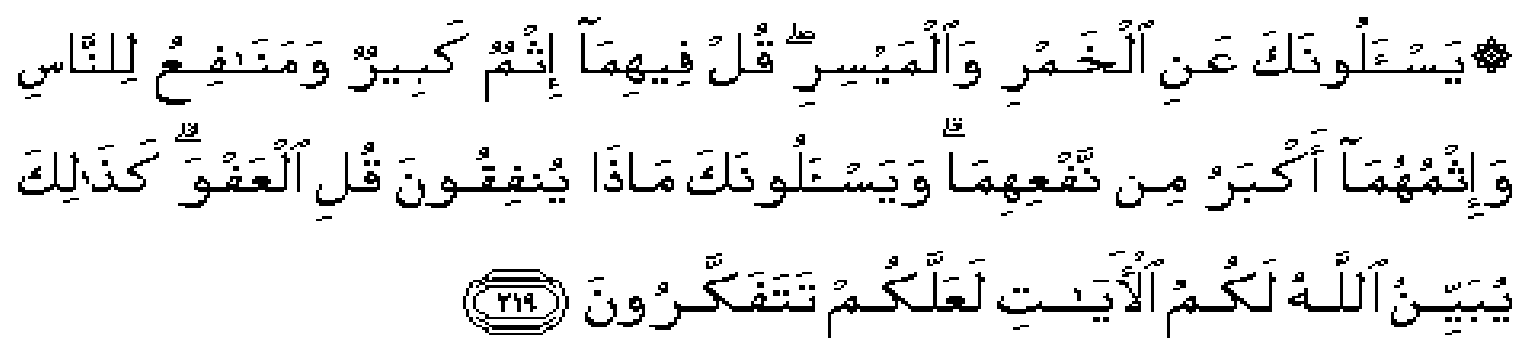

Meaning: "They ask you about khamar and gambling. Say: "In both there is a great sin and some benefit to mankind, but their sin is greater than its benefit." And they ask you what they spend. Say: "More than necessity" Thus Allah explains His verses unto you to think ".

After that, Allah SWT forbid liquor and gambling until doomsday. The Word of God in QS al-Maidah (5) verse 90:

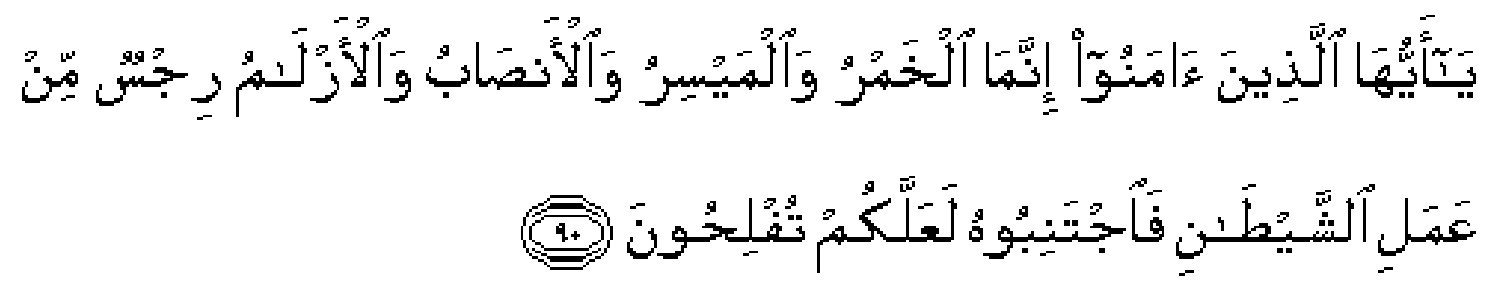

Meaning: $O$ ye who believe, verily (drink) khamar, gamble, (sacrifice for) idols, draw fate with arrows, is included acts of shaitan. So keep those deeds to good luck.

Prophet Muhammad SAW gave the drinker a duty law and sentenced takzir to the perpetrators of gambling. However, there is no information about the imposition of sentences against the perpetrators of both crimes before the decline of the prohibited verse. Therefore, the nasties that prohibit liquor and gambling do not have retroactive power. 


\section{Theft Crime}

Against the criminal act of theft of Islamic law stipulates that the perpetrator is punished with hand-cut, as determined by QS.al-Maidah (5) verse 38:

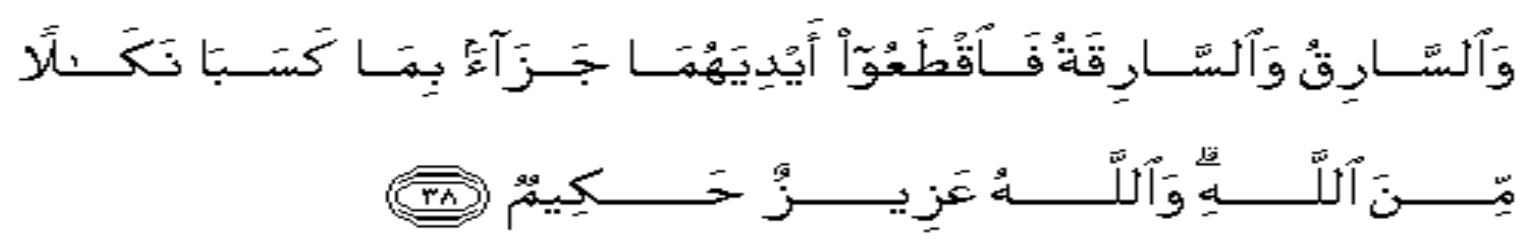

Meaning: The man who stole and the woman who stole, cut off both hands (as) retaliation for what they do and as punishment from God. Allah is Mighty, Wise.

From the various studies of the above verse, it is unknown to a single narrator to say that the passage has been applied to a criminal act of theft that occurred prior to the decline of the verse. Therefore, the law is not retroactive.

\section{Usury/Riba ${ }^{11}$}

Before the Islamic period, usury is usually done then Allah forbid it. Allah says in QS.al-Baqarah (2) verse 275 :

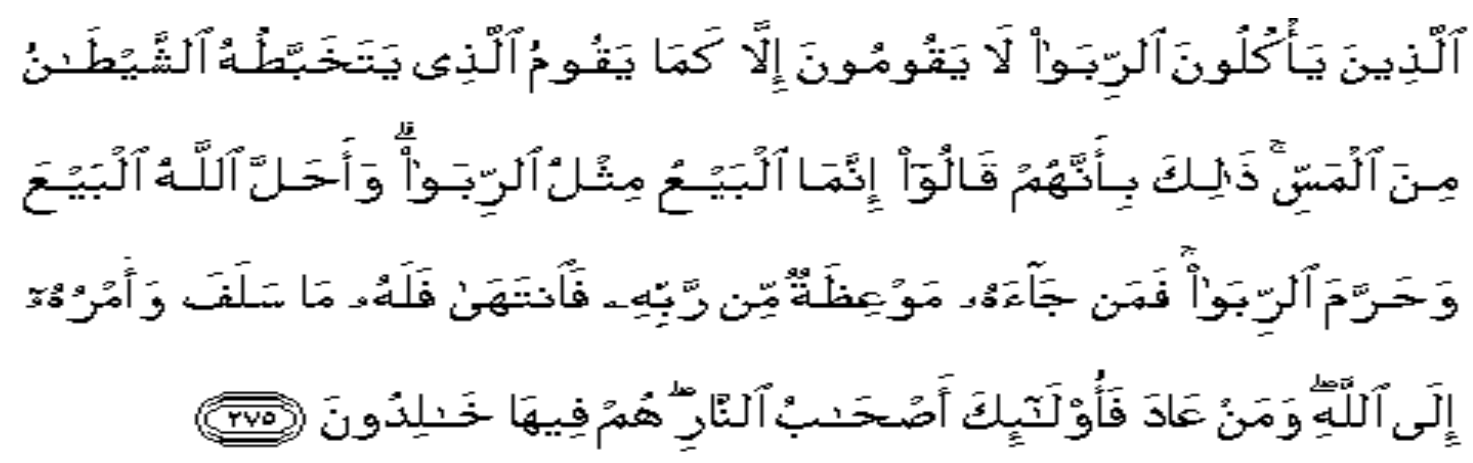

Meaning: The people who eat (take) usury cannot stand but like the establishment of people who conceded devils because of (pressure) madness. Their circumstances are thus, is because they say (opinion), the

\footnotetext{
${ }^{11}$ Riba there are two kinds: nasiah and fadhl. Riba nasiah is the more payment required by the person who lends. Riba fadhl is the exchange of an item with similar goods, but more in number because the person who exchanges such require, such as gold exchange with gold, rice with rice, and so on. The usury referred to in this verse of usury of multiplied ration is common in Arab societies of the age of ignorance. In the Digital Qur'an. 
real buying and selling is the same as usury, but God has justified the sale and purchase and forbid usury. Those who have reached to him the prohibition of their Lord, then continue to stop (from taking usury), then to him what he has taken first (before coming to ban); and its affairs (up to) to God. The one who returns (takes usury), then that person is the inhabitants of hell; they are eternal in it.

Another foundation in QS al-Baqarah (2) verses 278-279:

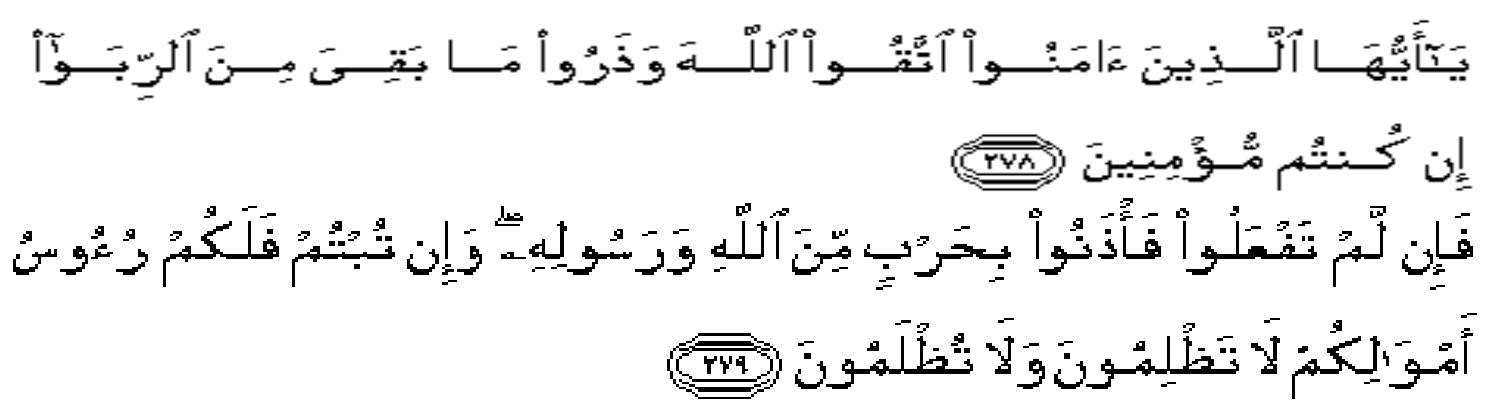

Meaning:

"O ye who believe, fear Allah and leave the rest of usury (if it is not collected) if you are believers.

So if you do not (leave the rest of usury), then know that Allah and His Messenger will fight you. And if you repent (from taking usury), then for you the principal of your treasure; you do not persecute or be persecuted. $"$

After the receiving this verse, all forms of usury are forbidden. According to the criminal code, the usury incurred before the discharge of the verse is not punishable. So the rules about the punishment of usury also do not apply retroactively.

Thus the above passages make it clear that in Islamic law these passages have no retroactive power. However, there is a clear passage, but there is another passage that does not expressly state.

This is in accordance with the basic rule of Islamic law which states that "nothing is laid down by law except the act which might be accomplished by mukalaf and known by it so as to make it sufficient to do 
it". Also the rule of other Islamic law "the act of mukalaf not be judged before the coming of a nas". ${ }^{12}$

So in accordance with the necessity of Islamic law to use profitable passages and give more benefit to the perpetrators, the logical consequence of this then:

- If the newly issued letter is enacted before a decision is made for a criminal offense, while the passage is more favorable to the offender, he should be tried on the basis of the new passage even if the offense he committed occurred at the time of the old validity.

- If a new pass is issued after the decision, while the passage is more favorable to the convicted person, then the penalty must be adjusted to the penalty stipulated in the new passage.

- If a new pass is issued after a decision has been made, while the passage is no longer views as a criminal offense, then decisions that have been granted under the old pass shall not be exercised. And if it has been implemented then the execution of punishment should be stopped.

- If the new passage threatens with more severe punishment, then the new passage does not apply to the perpetrator because the new passage is unprofitable to me and basically all criminal offenses are brought to justice under the prevailing laws at the time of the offense.

Based on the above description, it can be seen that according to the general rule in Islamic law, that the application of criminal law has no retroactive force. All the nas Syarak, its general and historical basics make such a case. However, non-retroactive principle can be disregarded based on the principle of "dlarar / danger" and "maslahat / goodness", which is criminal act which is very dangerous to society and on condition when bringing benefit to individual and society.

${ }^{12}$ Ensiklopedi Hukum Pidana Islam, op-cit, hlm.291. 
According to Sofjan Sauri Siregar ${ }^{13}$ in Islamic law there is a balance between the protection of individual interests and the protection of public interest. In retroactive principle, in Islamic law other than recognizing the principle of non retroactive, it also recognizes exceptions to the principle of non retroactive. It means that in certain cases the rule of Islamic criminal law can retroactive namely against criminal acts that are considered very harm to the people interests and bring benefit to individuals and communities in order:

- maintaining security,

- good things, and

- keep the system in the community.

Aagainst the crime of qazaf (accusing adultery) and hirabah (general disorder) applied retroactive provisions (retroactive). Hence, in addition to non-retroactive principle oriented to the protection of individual interests but in the framework of equilibrium/justice then also accommodate the importance of protecting the interests of the community.

The importance of protecting the interests of the community as a spouse for the protection of individual interests, it has not been accommodated in Article 1 paragraph (2) of the Criminal Code. Even so in the development of the formulation of Article 1 paragraph (2) of the Criminal Code / WvS experience changes / expansions as contained in the Criminal Code Act 2015.

The development of non-retroactive principle can be seen in the formulation of the Criminal Code Bill as follows:

(1) In the event of any amendment to the laws and regulations after the act has occurred, new laws and regulations shall be applied in accordance with the prevailing laws and regulations where they are favorable to the producer.

(2) In the event that after the decision of the crime of acquisition has a permanent legal force, the acts that occur no longer constitute a

${ }^{13}$ Interview with Sofjan Sauri Siregar, 12 December 2016. 
criminal offense according to the new legislation, the execution of the decision of the crime shall be abolished.

(3) In the event that after the decision of criminal proceedings obtains a permanent legal force, the acts committed shall be punishable by a lighter punishment under the new legislation, then the execution of the punishment shall be subject to criminal limits in accordance with the new legislation.

According to the Criminal Code Draft, the retroactive idea applies more favorable/mitigating rules in the event of a change of law, not only apply to the accused before the judge's permanent decision, but also valid (extended) to the convicted person or after obtaining a fixed. However, the extension as in the formulation of the Criminal Code Draft can be said to still be oriented to individual interests, because it does not formulate what if the interests of the community want, meaning there is no balance between individual justice and community justice (mono-dualistic).

Based on the above description, it can be seen that the principle of non-retroactive both contained in the Criminal Code and the rules in the Criminal Code can be said not yet in accordance with the values of religious wisdom, because the principle of retroactive only oriented to the interests of the individual and not oriented to the interests of society public and sense of community justice).

\section{Ideal Reconstruction of Retroactive Principle Based on the value of Religious Wisdom.}

Based on the values of religious wisdom, especially from the perspective of Islamic law, in the case of any change in legislation in principle, non-retroactive principle is applied, but the principle can be disregarded in accordance with the principle of "dlarar" and "maslahat". This means that in certain cases it can be retroactive as long as the act is very feasible for the security and legal system in society and with retroactive will bring benefit to the perpetrator, victim and society. 
In addition, deviations from non-terrestrial principles are also based on the underlying foundation that preventing vices should take precedence over benefits. By such a measure, the non-retroactive principle of Islamic law is oriented towards the balance of protection of individual and community interests.

Based on the above statement, the non-retroactive principle reconstruction in the New Criminal Code should be formulated based on the values of balance between social values and human values, so that the formulation policy of "transitional rules" is not merely oriented to the interests of the individual (offender) only, but also oriented to the public interest. This means that irregularities against non-retroactive principles are not only when they meet the criteria/favorable criteria to suspects/defendants only, but also when benefiting the interests of society (protection of public interest and sense of community justice).

Based on the above issues, the reconstruction of retroactive principle in the draft of the Criminal Code proposed the formulation to be:

\section{Section 2}

(1) In the event of a change of legislation after the act has occurred, new laws and regulations shall be applied in accordance with the existing laws and regulations which are applicable to the benefit of the manufacturer and to the benefit of the public for certain criminal offenses prescribed by law.

(2) In the event that after the decision of the crime of acquisition has a permanent legal force, the acts occur no longer constitute a criminal offense according to the new legislation; the execution of the decision of the crime shall be abolished.

(3) In the event that after the decision of criminal proceedings obtains a permanent legal force, the acts committed shall be punishable by a lighter punishment under the new legislation, then the execution of the punishment shall be subject to criminal limits in accordance with the new legislation. 
Proposed changes in the formulation of the principle of retroactive can be described in the following table:

Table 3

Comparison of Active Retro Principles

\begin{tabular}{|c|c|c|}
\hline $\begin{array}{l}\text { Criminal } \\
\text { Code }\end{array}$ & Criminal Code Draft & $\begin{array}{l}\text { Reconstruction In the } \\
\text { Upcoming Criminal Code }\end{array}$ \\
\hline $\begin{array}{l}\text { If after the act } \\
\text { has been } \\
\text { made there is } \\
\text { a change in } \\
\text { the } \\
\text { legislation, } \\
\text { the most } \\
\text { enforceable } \\
\text { rule for the } \\
\text { defendant is } \\
\text { used }\end{array}$ & $\begin{array}{l}\text { In the event of any } \\
\text { change in legislation } \\
\text { after the act occurs, } \\
\text { new legislation is } \\
\text { enacted in accordance } \\
\text { with the prevailing } \\
\text { legislation provisions } \\
\text { where it is } \\
\text { advantageous for the } \\
\text { manufacturer }\end{array}$ & $\begin{array}{l}\text { In the event of any change in } \\
\text { legislation after the act has occurred, } \\
\text { new laws and regulations shall be } \\
\text { applied in accordance with prevailing } \\
\text { laws and regulations where profitable } \\
\text { for the producer and to the benefit of } \\
\text { the public for certain offenses } \\
\text { prescribed by law. }\end{array}$ \\
\hline
\end{tabular}

Beside from the study of Islamic law the exception to nonretroactive principles is also based on the emergence of developments in legislation outside the Criminal Code, they are:

a. The provision in the Elucidation of Article 4 of Law No.39 / 1999 on Human Rights states that "the right not to be prosecuted on the basis of retroactive law may be exempted in the case of gross violations of human rights classified as crimes against humanity"

b. Article 43 of Law No.26 / 2000 on Human Rights Court which states that "grave human rights violations that occurred before the enactment of this Act were examined and decided by the ad hoc Human Rights Court".

c. The exit of Perpu No.2 / 2002 (October 18, 2002) jo.UU No.16 / 2003 (4 April 2003) which enacted Perpu No.1 / 2002 on the 
Eradication of Terrorism (into Law under Law No. 15/2003) on bomb incidents Bali October 12, 2002. ${ }^{14}$

The exclusion policy on non-retroactivity is not only found in legislation outside the Criminal Code, but it is also seen when studying international legal references on international crime or international criminal law.

As it is known in international customary law, it has acknowledged that the non-retroactive principle of application does not apply to serious crimes including gross violations of human rights. Examples of retroactive enforcement are cases of judicial proceedings of the Nuremberg Courts, Tokyo, Rwanda and in the former Yugoslav colony. All of the legal principles applied in the judicial process of the Tribunals have been recognized as an integral part of international law in practice because all decisions of the Court are binding and acknowledged by the international community and all defendants shall be required to serve the sentence imposed by the Court. ${ }^{15}$

The views of the Criminal Law Experts on the retroactive imposition, there is still no similar opinion among experts. The conventional view still asserts that the non-retroactive principle is the absolute legal principle and this legal principle is the general principle of the criminal law and is universal.

In the 1945 Constitution of 1945 and the second stage changes until the fourth stage of change, it is also affirmed in Chapter XA on the specific Human Rights of Article 28 I with certain limitations as set forth in Article $28 \mathrm{~J}$. In reference to human rights, it is known that the right not to be prosecuted by a retroactive law is not an absolute right but rather a relative right. According to Romli Atmasasmita ${ }^{16}$ the last sentence of the

\footnotetext{
${ }^{14}$ With respect to sub-c, in the decision of the Court No.Perkara 013 / PUU-1/2003, Law No.16 / 2003 is declared contradictory to the 1945 Constitution and has no binding legal force, although among the 9 (nine) judges of the Constitutional Court there are 4 judge who expressed "dissenting Opinion" (different opinion).Dalam Barda Nawawi Arief, Perkembangan Asas-Asas Hukum Pidana Indonesia, Badan Penerbit Universitas Diponegoro, Semarang, 2007, hlm 4-5.

${ }^{15}$ Romli Atmasasmita Penerapan Hukum Pidana dan Asas Non-Retroaktif dalam Pemberantasan Korupsi, Sumber: http://www.transparansi.or.id, dan http://www.transparansi.or.id/berita/beritamaret2005/berita2 310305.html <http://jodisantoso.blogspot.com/2007/09/penerapan-hukumpidana-dan-asas-non.html > Diunduh pada 2 juli 2016 pukul 20:08 WIB.

${ }^{16}$ Ibid.
} 
formulation of Article 28 I of the 1945 Constitution and its amendments, "under any circumstances" is not in line with Article $28 \mathrm{~J}$ and Article 29 of the Universal Declaration of Human Rights of the United Nations.

On the other hand, the modern view of retroactive application is in line with the development of international criminal law and the development of international conventions on organized transnational crime including corruption, money laundering, terrorism and narcotics and the development of the International Convention on The International Criminal Court.

The twentieth-century opinion or view of the application of nonretroactive principles affirms that in accordance with the development of time and in the context of a particular crime which poses a threat to the peace and security of humankind, the introduction of a non- retroactivity can be ruled out, selectively and finite. This connection has been applied since the court proceedings of the Nuremberg Court (1946) to the ad hoc Tribunal for crimes against genocide and crimes against humanity in the former Yugoslav colony.

This is in line with Jan Remmelink's view ${ }^{17}$ of the enforcement of the criminal law in the Netherlands. The modern view also refers to the opinion of Jan Remmelink which asserts that retroactive power of criminal law occurs in transitional legal situations. He described his opinion as follows: "An important function is played by the second paragraph of Article 1 , which is an exception, if not to be said to be irregularities against the prohibition of retroactive penal application as set forth in the first paragraph." In connection with the sound of Article 1 paragraph (2) and Jan The Remmelink, has been questioned which law is enacted in transitional legal situations, and in its description Jan Remmelink affirms that under such circumstances, the law applicable after a crime is a favorable law, then retroactive enforcement is permitted.

\footnotetext{
${ }^{17}$ Jan Remmelink, Hukum Pidana Komentar Atas Pasal-Pasal Terpenting dari KUHP Belanda dan Padanannya dalam KUHP Indonesia, PT.Gramedia Pustaka utama, Jakarta, 2003. hlm 365366. 
Firmly Jan Remmelink ${ }^{18}$ says that there are two alternative interpretations of the retroactivity of a criminal provision:

a) Formal teaching. As far as formal teaching is concerned, the term "wetgeving" (the legislator) in the provisions (Dutch Criminal Code) as strafwetgeving, so in the context of establishing an act as a crime (strafbaarstelling). In this way, it will be taken into account only those changes that directly touch the criminal provisions themselves, while those relating to or lying within administrative law may be ignored. "

b) Material doctrine, according to limited material teachings, which take into account material changes that from or through this change (legislation, pen.) must be a change of perspective or the understanding of the lawmaker about merit (propriety, pen .) Such action is for criminal penalties. This requirement was used by the Dutch Hooge Raad who called it, creative-restrictive interpretation, not for profit, but precisely for the loss of the defendant.

Based on the development of international criminal law and the development of international conventions mentioned above, in the context of certain crimes that pose a threat to the peace and security of humankind, and crimes against humanity, the application of nonretroactive legal principles can selectively and limitedly set aside.

From the above study it can be concluded that the acceptance of exceptions to non-retroactive principles that are oriented to the interests of the community are based on:

- Balance the values of religious wisdom

- The development of legislation outside the Criminal Code

- The development of international conventions,

- Legal expert opinion.

\footnotetext{
18 Ibid.Lihat pula Romli Atmasasmita, Perbandingan Hukum Pidana Kontemporer, Fikahati Aneska, Jakarta, 2009, hlm.54.
} 
The foundation above requires the formulation of transitional rules (retroactive) in the upcoming Criminal Code formulated policies oriented to the idea/value of balance between protection of individual interests and protection of public interest. The formulation of the retroactive principle in the proposed Criminal Code law is proposed as: "In the case of a change of laws and regulations after the act occurs, new laws and regulations apply to existing laws and regulations which are of benefit to the producer and to the benefit of the community for acts certain penalties prescribed by law ".

The definition of a specific crime in the above suggestion is for crimes which are a threat to the peace and security of the world (crime against humanity), and it must be established by law.

Indeed such a proposal is contradictory to the sound of Article $28 \mathrm{i}$ of the 1945 Constitution which states that "the right not to be prosecuted on the basis of retroactive law is a human right which cannot be reduced under any circumstances", but based on the above studies should be the application of non -retroactive is not absolute, but in certain cases it is necessary to selectively and selectively exclude, because national criminal law to be built is based on the balance of Pancasila values.

\section{E. CONCLUSION}

1. Based on the values of religious wisdom especially from the perspective of Islamic law is in the case of any change in legislation in principle apply non-retroactive principle (not retroactive), but in certain cases the principle can be diverged in accordance with the principle of "dlarar" and "Maslahat". This means that deviations from non-retroactivity principles can be enforced as long as they are very valuable for the security and legal system in society and will bring benefits to the perpetrators, victims and the community. By such a measure, the non-retroactive principle of Islamic law is oriented towards the balance of protection of individual and community interests. 
2. The formulation of the retroactive principle in the proposed KUHP RUU shall be proposed as: "In the case of a change of laws and regulations after an act has occurred, new laws and regulations shall be applied in accordance with existing legislative provisions when profitable for the maker and beneficial to the public interest for certain criminal offenses prescribed by law ".

\section{References}

Abdurrahman I. Doi, Shari 'ah The Islamic Law, Tindak Pidana Dalam Syari 'at Islam, Penerjemah Wadi Mustari dan Basri Iba Asghari, Rineka Cipta, Jakarta, 1992.

Abdul Qadir Audah, Ensiklopedi Hukum Pidana Islam, Judul Asli AtTasyrial-Jina'i al-Islamy Muqaranan bil Qanunil Wad'iy, PT.Kharisma Ilmu, Bogor, Jilid II, 2007.

Barda Nawawi Arief, Perkembangan Asas-Asas HukumPidana Dalam Konsep KUHP (Perspektif Perbandingan Hukum Pidana), Pustaka Magister, Semarang, UNDIP, Semarang, 2007.

Ensiklopedi Hukum Pidana Islam, Jilid I-V, PT.Kharisma Ilmu, Jakarta, 2007.

Ensiklopedia Hukum Islam, Jilid I-VI, Ichtiar Baru Van Hoeve, Jakarta, 1997.

Jan Remmelink, Hukum Pidana Komentar Atas Pasal-Pasal Terpenting dari KUHP Belanda dan Padanannya dalam KUHP Indonesia, PT.Gramedia Pustaka utama, Jakarta, 2003.

Nyoman Serikat Putra Jaya, Beberapa Pemikiran Ke Arah Pengembangan Hukum Pidana, PT Citra Aditya Bakti, Bandung, 2008.

Romli Atmasasmita, Perbandingan Hukum Pidana, CV. Mandar Maju, Bandung, 2000

------------, Perbandingan Hukum Pidana Kontemporer, Fikahati Aneska, Jakarta, 2009 Penerapan Hukum Pidana dan Asas Non-Retroaktif dalam Pemberantasan Korupsi, Sumber: http://www.transparansi.or.id, dan http://www.transparansi.or.id/berita/berita- 
maret2005/berita2 310305.html

<http://jodisantoso.blogspot.com/2007/09/penerapan-hukumpidana-dan-asas-non.html> Diunduh pada 2 juli 2016 pukul 20:08 WIB

Teungku Muhammad Hasby Ash-Shiddieqy, Pidana Mati Dalam Syari'at Islam, Pustaka Rizki Putra, Semarang , 1997. 1997.

, Falsafah Hukum Islam, Pustaka Rizki Putra, Semarang, sal Islamic Declaration of Human Right 